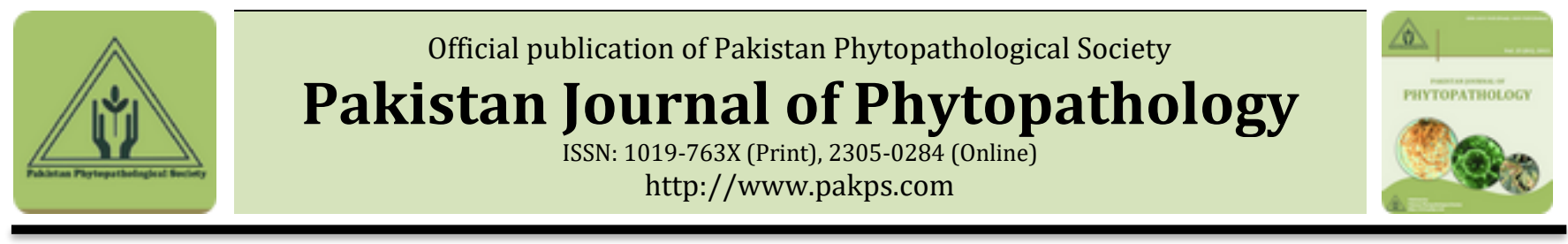

\title{
UNDERSTANDING INVASIVE PLANT MYCOPARASITES AND THEIR REMEDY THROUGH ADVANCED MOLECULAR APPROACHES
}

\author{
Aqsa Parvaiz, Ghulam Mustafa*, Faiz A. Joyia \\ Center of Agricultural Biochemistry and Biotechnology (CABB), University of Agriculture (UAF), University Road, \\ Faisalabad 38040, Punjab, Pakistan.
}

\begin{abstract}
A B S T R A C T
Fungi are historically notorious pests that have threatened availability of quality food. Several invasive species have appeared to be destructive for valuable crop species and even led to famine in certain severe cases. Surveillance and eradication of these disastrous microbial invaders is dependent on their sentinel behavior. Molecular Biology has helped to great extent in understanding these epidemic agents. Plant defense system as well as plant microbe interaction have well been explored and proved quite fruitful in understanding metabolic pathways involved in pathogenesis and defense response. Ultimately, researchers are able to define strategies for the control of these invasive pathogens. Genome editing has successfully been employed to develop pathogen resistant crops. Antifungal proteins have been expressed through transgenic technology to develop disease resistant plants. A few have proved to be the real success stories whereas others are at the stage of infancy. This review is an update about research work accomplished to-date, for the characterization and identification of fungal pathogens, metabolic pathways activated during plant pathogen interaction, advancements in the detection of fungal pathogens and transgenic plants developed to withstand pathogen attack.
\end{abstract}

Keywords: Invasive fungal pathogens, Plant defense response, Molecular diagnosis, Transgenics, Cisgenic approaches.

\section{INTRODUCTION}

Human population is increasing at a pace of 80 million per annum which is quite alarming. Sharply increasing population coupled with shrinking cultivable land, water scarcity and expanding urbanization demands huge quantity of quality food from decreased cultivated land and lower input supplies (Nelson \& Smith, 1993). Under these circumstances, provision of food to ever increasing population is really a challenge. All this can be achieved by the introduction of better performing varieties, improving cultural practices and discovering innovative methods for the control of invasive pathogens. Researchers have contributed a lot to combat all of the aforementioned limitations (Oerke \& Dehne, 2004).

Submitted: May 25, 2018

Revised: June 07, 2018

Accepted for Publication: July 05, 2018

* Corresponding Author:

Email: drmustafa8@gmail.com

(C) 2017 Pak. J. Phytopathol. All rights reserved.
Fungal pathogens are destructive for almost all of the plant species including cereals, fiber crops, sugar crops, vegetables, flowers, fruits and tree plants. More than 125 million tons of the major food crops including wheat, maize, rice, soyabean and potatoes is deteriorated by fungal infections each year (Matthew et al., 2012). This lost crop produce could be enough to feed all the people who don't have food to eat. Certain diseases i.e. potato late blight, rice blast, wheat stem rust, corn stem rust, soybean rust and smut in maize, red rot in sugarcane are known to affect $50 \%$ of the crop produced. In tree plants, too, sheesham dieback has resulted in severe destruction of this important timber tree in certain regions of the world (Anonymous, 2012). Plant yield is limited to great extent due to devastating effects of fungal pathogens. Premier management practices, to control these pests were development of disease resistant varieties, use of chemical fungicides and biocontrol agents. These management practices are of pivotal importance but have certain limitations including 
high cost, side effects and lower efficiency. Emergence of new pathogens has added to these limitations, as a result major portion of the crop produce is lost due to fungal infections. Understanding mode of infection of newly emerged pathogens and their mode of interaction with host plant will prove a great milestone for their control (Fisher, 2013). Further employing transgenic technology to develop pathogen resistant plants against a range of pathogens is really of great importance. This review highlights such updates regarding plant pathogen interaction, resistance development against chemical fungicides and significance of transgenic technology to develop resistant plant against disastrous fungal pathogens.

Fugal pathogens as life threatening parasites for plants: Fungi are classified into four major phyla including Zygomycota, Basidiomycota, Ascomycota and Oomycota. Zygomycota are sexually reproduced by forming the conjugating gametengia, involving the production of zygospores and zygosporangia. They have aseptate hyphae and also called filamentous fungi. Basidiomycota have club shaped fruiting bodies called basidia which are present at the tip of hyphae. They have sexual reproduction. Most of the edible fungi belong to this phylum. Ascomycota is also called sac fungi due to formation of sac-like structure, ascus. They are produced both sexually and asexually. This group includes commercially important fungi. Oomycota are not true fungi and are sometimes ranked as lower fungi. They have many structural similarities with fungi but major difference is in the composition of cell wall that is composed of beta glucans and cellulose instead of chitin (Samanta, 2015).

We discuss here, few of the plant pathogens which affect crop plants seriously and may even lead to complete crop failure(Dean et al., 2012). Irish potato famine is one of the familiar examples to undersatnd level of disastrousness of fungal pathogens. Potato has been the main staple food in European countries. One third of Irish population was dependent on potato as a staple food at times (Reader, 2009). Unluckily, Phytophthora infestans (which was first appeared in North America) moved to this region during 1845 and spread rapidly in Great Britain and Ireland etc. The disease extent was so severe that it led to complete failure of the crop resulting in historic Irish famine. Almost one million people died whereas more than one that were forced to migrate to other countries (Turner, 2005). Still, Irish population is one third of the actual population as was at the time of famine (1840s) (Yoshida et al., 2013). The casual agent of Irish famine (Phytophthora infestans) is an extremely virulent pathogen and exists alongwith other noxious species i.e. ipomoeae and mirabilis (Haas et al., 2009). It normally multiplies through sexual-reproduction and has adapted a high level of genetic and phenotypic diversity.

Magnaporthe oryzae is a filamentous ascomycetic fungi which causes the most disastrous disease of rice blast (Ou, 1980). Blast may result in $10-30 \%$ losses to the crop yield and may even be epidemic in conditions favorable for pathogen. In addition to rice, this pathogen also infects grasses millet, wheat and barley (Couch et al., 2005). Botrytis cinerea (grey mold) is a broad spectrum fungal pathogen known to infect more than 200 plant species. These fungi have been most drastic for wine and table grapes and caused heavy economical losses in South Africa (SA Rand 25 million/year), Australia (AUS $\$ 52$ million/year) and Chile (US\$22.4 million/year) (Scholefield \& Morison, 2010). The fungus is a typical necrotroph which causes infection by inducing programmed cell death (PCD) in the host (van Baarlen et al., 2007). Advancements in genomics approaches have helped a lot to explore this pathogen by characterizing its genome and by employing molecular tools to understand its mode of infection. Puccinia species including Puccinia tritici, Puccinia striiformis and Puccinia graminis cause rust diseases in wheat including yellow rust (stripe rust), brown rust (leaf rust) and black rust (stem rust). These fungi have heteroecious, macrocyclic lifecycles and are obligate, biotrophic basidiomycete. (Rutter et al., 2017). Obligate biotrophs obtain their nutrients through haustoria (specialized feeding structures which are embedded inside the plant cells). They overwhelm the host defence response by developing particular infection structures (Voegele \& Mendgen, 2011). Historically, stem rust has proved to be the most notorious resulting in complete destruction of wheat crop. In ancient Rome, people were so afraid of this disease that rituals were performed to save their crop. Wheat rust, also known as polio of agriculture, is spreading all over the globe and is causing drastic losses to this cereal food crop (Singh et al., 2004). North America has already faced similar type of threat in 1950's where more than $40 \%$ of the crop was wiped out due to rust. Since then, rust-resistant lines have 
been commercialized by investing millions of dollars, as a result wheat crop is comparatively secure and farmers are growing with confidence (Kolmer, 1996). A mild out-break was reported in Uganda during 1999 where fungus was reported to attain certain lethal mutations, as a result, most of the cultivated varieties became susceptible (Pretorius et al., 2000). This insisted researchers that consistent efforts are direly needed to conduct research to understand plant pathogen interaction and to develop new varieties with elevated level of resistance against infectious fungal pathogens. Fusarium graminearum is a disastrous pathogen for all cereal species which may infect a wide range of crops including cotton, tomato, banana and melon (Michielse \& Rep, 2009) and is now emerging as human pathogen(Nucci \& Anaissie, 2007). It normally co-infects and co-exists with other Fusarium species and infects floral tissues. Long time storage of infected cereals results in increased mycotoxin level in the grains (Magan et al., 2010). Blumeria graminis is an ascomycete that causes powdery mildew of grasses including barley and wheat. It may affect crop growth and cause severe reduction in yield. Mycosphaerella graminicola is another disastrous ascomycete which causes blotch disease (Septoria tritici) in wheat. This pathogen is more infectious in warm humid regions (Orton et al., 2011). Fungus makes intracellular colonies and remains inside the plant for more than seven days without any symptom. Then, it results in the formation of leaf lesions ultimately resulting in complete destruction of the crop (Keon et al., 2007). One of the most common and important genera of plant pathogenic fungi is Colletotrichum. Almost each of the crop plant is susceptible to this pathogen and it may cause blights, post-harvest rots and anthracnose(Prusky, 1996). Most of the Colletotrichum species initiate infection through biotrophic phase accompanying with large intracellular primary hyphae. Later on fungus switches to critical necrotrophic phase accompanying with narrower secondary hyphae.

Aspergillus flavus is notorious to produce aflatoxins which may affect quality of almost each and every stored food product. Crop plants growing in the warm, humid climate (maize, cotton, groundnut) are more prone to be infected by this pathogen, as a result seed quality is seriously affected and may even completely be lost. Anyhow, all of the Aspergillus strains do not produce aflatoxins, rather few are used in the preparation of quality food products.

Fungi: plant interaction and defense response: Fungal pathogens are one of the serious disastrous entities that cause serious yield losses to crop plants. Scientists have worked out that how these phytopathogens interact with plant cell and ultimately cause death of the invaded cell. Plant pathogenic fungi are categorized into biotrophic, necrotrophic and hemibiotrophic phases of interaction (Selin et al., 2016). During the biotrophic phase of interaction, plasma membrane of plant invaginates around interacellular hyphae (IH). Similar type of interaction has also been observed during haustoria formation. A few of the plant species don't follow this interaction i.e. Colletotrichum lindemuthianum-bean interaction (Green et al., 1995). This interface results in plantfungal interaction which ultimately plays crucial role in the establishment and maintenance of biotrophy and ultimately helps to find out ways to control fungal pathogens. Necrotrophic fungi produce cell wall degrading enzymes such as pectin lyases, endo-PG (endo-polyglacturonase), $\alpha$ and $\beta$-galactopyranosidase, $\alpha$-arabinofuranosidase. During hemibiotrophic phase of interaction, the pathogen first establishes biotrophic phase followed by nectrotrophic phase which shifts to necrotrophic phase, ultimately resulting in death of the host cell (Perfect et al., 1999).

Fungal pathogens trigger death of the host cells, either by releasing toxins or inducing PCD (programmed cell death) in response of ROS (reactive oxygen species) production (Barna et al., 2012). Some necrotrophic fungi also promote susceptibility of host cell by releasing toxic effectors. These effectors down-regulate the resistance proteins and defence enzymes by interrupting regulatory/signaling pathways (Wang et al., 2014). Aspergillus mycotoxin induces necrotic lesions through down-regulation of antioxidant defence enzymes and oxidative burst induction at high ROS level (Peng et al., 2010). Fusaria releases nivalenol, T-2, diacetoxyscirpenol, HT-2, SMs fusarenon, DON and neosolaniol which inhibit seed germination and induce PCD (programmed cell death) in tomato protoplast (Paciolla et al., 2004). In Arabidopsis thaliana, Fusarium sporotrichioides induce production of hydrogen peroxide, callose deposition, cell death and accretion of salicylic acid and DON (deoxynivalenol) toxin repressed translation in Arabidopsis cells without 
inducting the elicitor-like signaling pathway (Nishiuchi et al., 2006).

Defensive strategies opted by plants to combat fungal pathogens: No doubt, fungal pathogens are the most notorious ones and have even resulted in famine during certain eras. Evolution of certain defense mechanisms have helped plants to cope with these disastrous pathogens. These defense strategies may be categorized into chemical and physical barriers that obstruct pathogen entry and infection. Morphological, biochemical and molecular changes improve defense ability of plants including upregulation of defense related genes, oxidative bursts, programmed cell death and production of antimicrobial compounds (Bari \& Jones, 2009).

Plants have evolved a two-layered innate immunity. Pattern recognition receptors (PRRs: a set of defined receptors) are used to attain the primary innate immunity that is first line of defense. These receptors are involved in the recognition of conserved MAMPs (microbe-associated molecular patterns). MAMPs recognition persuade the primary defense responses that include deposition of callose, amendments in cell wall and accretion of defense related proteins such as chitinases, glucanases and proteases by which pathogens are negatively affected. Elongation Factor Tu (Zipfel \& Felix, 2005), lipopolysaccharides, flagellin, chitin and $\beta$ glucans are other microbe-associated molecular patterns (MAMPs) effective against plant pathogens (de Wit, 2007).

True pathogens may suppress innate immune system of plants. Several mechanisms inhibit activation of primary defense responses and recognition of MAMPs in fungal, bacterial and viral pathogens (Vivier \& Malissen, 2005). Plants have developed secondary defense responses to defend themselves against true pathogens that are triggered by identification of effectors or effectormediated trepidations of host targets (Jones \& Dangl, 2006). These effectors and their trepidations are surveilled by resistant proteins (RPs) and secondary defense responses are initiated which frequently inhibit hypersensitive response (HR) with further defense responses that blocks growth of pathogens. RP detects the specific host targets whereas induction of hypersensitive response (HR) is non-specific and is generally activated against drastic plant pathogens (de Wit, 2007).
Plants produce a wide variety of pathogenesis-related proteins including glucanases, chitinases, chitosanses and metallothionine. Thirty-three PR proteins have been explored in tobacco, more than thirty in Norway spruce and twenty in sugar beet (Van Loon, 1997). Chitinases are enzymes involved in the breakdown C1-C4 linkage of two successive chitin N-acetyl-Dglucosamine monomers. They exist in plants, animals, fungi and bacteria. Chitin is commonly present in the exoskeleton of arthropods and fungal cell wall (Bartnicki-Garcia, 1968). Plant chitinases inhibit fungal growth and have ability to degrade chitin that is major component of fungal cell wall (Broekaert et al., 1988). $\beta$-1,3-glucanase play a major role in plant defense response and belongs to PR-2 family of pathogenesis-related proteins. It is also present in fungi, bacteria, yeast, insects, fish and actinomycetes (Pan et al., 1989) and is involvedin the cleavage of $\beta$ 1,3-glucan by breaking down $\beta$-1,3-glucosidic bonds (Simmons, 1994). $\beta$-1,3-glucan is an important structural component of cell wall in many pathogenic fungi but major constituent is chitin (Adams, 2004). PG (polygalacturonase) is a cell wall degrading enzyme that catalyzes release of oligosaccharides from the plant cell wall, thus elicits to activate defense mechanism in plants (Walker-Simmons et al 1983). PGIP is a protein present in the plant cell wall that precisely hinders PG activity (Albersheim \& Anderson 1971). It has also been proved to slow down hyphal extension rate which results in activation of other defense responses (Figure:1) (Cervone et al., 1986). Systemic acquired resistance helps to protect plants from pathogen attack at sites away from primary and secondary immune responses. Whenever pathogen infects any plant part either leaves or stem, systemic resistance is induced simultaneously alongwith local primary and secondary immune responses. Systemic acquired resistance (SAR) depends upon various plant hormones i.e. salicylic acid, ethylene, jasmonic acid and abscisic acid or combination of these and is effective against a wide range of infectious pathogens (Grant \& Lamb, 2006)These hormone dependent defense systems are active against insect pests and microbial pathogens (De Vos et al., 2005). Anyhow, the level of effectiveness of these resistance responses and their dependence on hormones varies from plant to plant or species to species. 


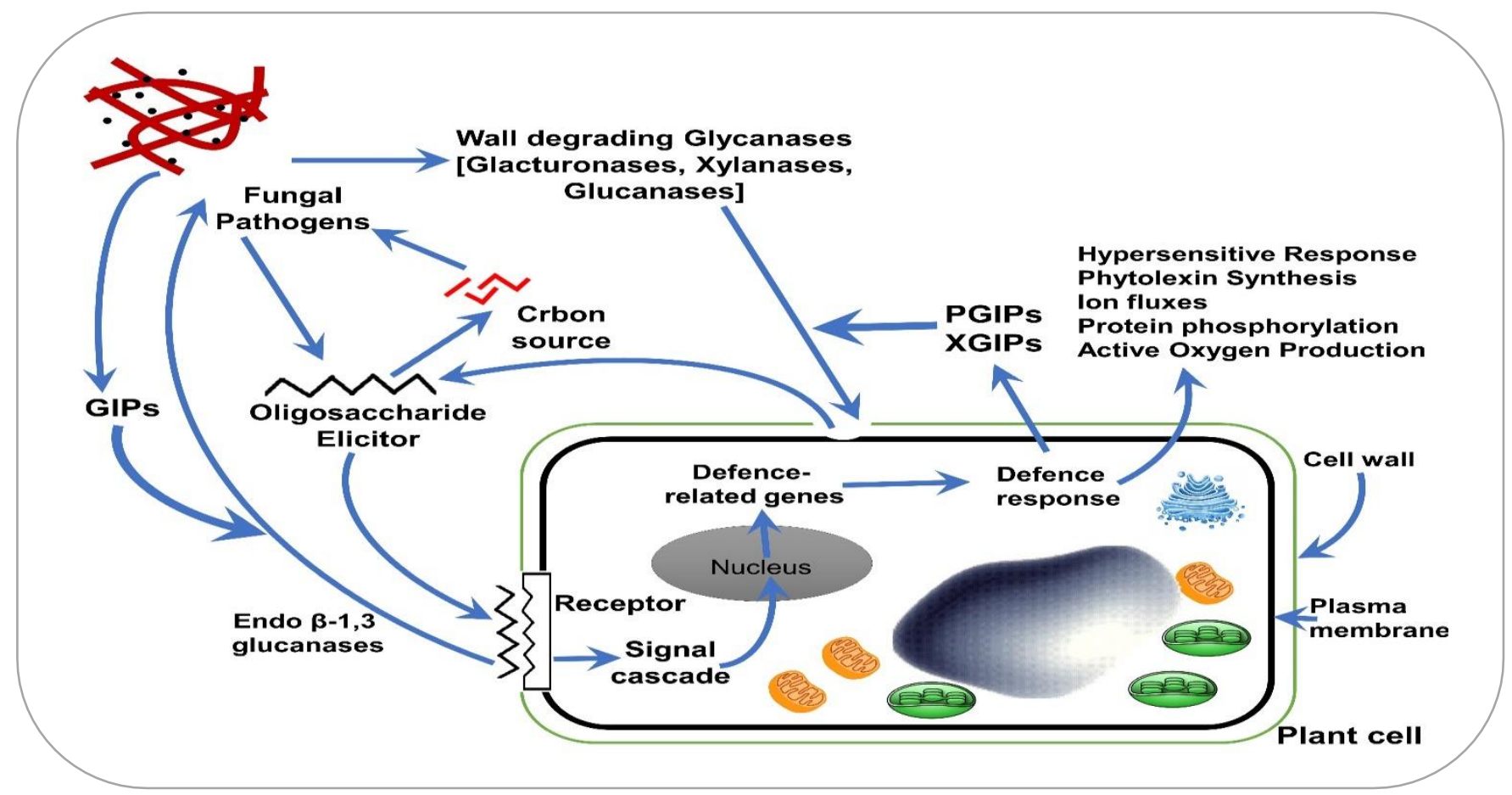

Figure 1: Pictorial representation showing interaction of fungal pathogens with plant and various defense strategies opted by plants to combat mycoparasites.

Pathogen infection produces methyl salicyclate which acts as aninducer for the activation of systemic acquired resistance. Exogenous application of salicylic acid enhances resistance by the induction of pathogenesis related genes (Park et al., 2007). Besides, ethylene and jasmonic acid are linked with defense against necrotrophic pathogens and pests. Jasmonic acid/ethylene and salicylic acid defense mechanisms interact synergistically against pathogen infection although they are antagonistic (Beckers \& Spoel 2006). Nature of pathogens decides about the activation of defense signaling pathways. These pathways may be activated synergistically depending upon the extent of infection (Adie et al., 2007). However, under field conditions, plants are attacked by multiple pathogens simultaneously which require diverse defense mechanisms to be triggered.

Plant-pathogen interaction produces AOS (active oxygen species) such as superoxide anions $\left(\mathrm{O}^{-2}\right)$, hydroxy radicals $(\mathrm{OH} \bullet)$ and hydrogen peroxide (H2O2). Baker and Orlandi, 1995). AOS play pivotal role in strengthening plant cell wall and improves signal transduction for enhanced resistance against pathogens. In addition, chloroplasts also play significant role in plant defense mechanism as is the site for biosynthesis of signaling compounds such as salicylic acid, jasmonic acid, nitric oxide and reactive oxygen species (ROS) (Lee et al., 2015). PCD (programmed cell death) is also regulated by above mentioned signaling compounds.

Advanced approaches to overcome fungal pathogen infestation: Since the beginning of agriculture, farmers have been striving hard to protect crops from harmful pests including fungi, bacteria, viruses, mites, rodents, nematodes, insects and weeds. Various chemical, biological and integrated approaches have been employed to combat these pathogens. With the advancements in research, innovative strategies have been developed and employed to develop plants having ability to withstand these drastic yield limiting agents (Oerke, 2005).

No doubt, breeding has contributed a lot to develop resistant crop varieties, better tolerant to fungal pathogens and other devastating agents. Conventional techniques have been used to develop pathogen resistant genotypes by stacking antifungal genes in various crops. Conventional methods to control pathogens had been very effective but insecticides, fungicides and bactericides are toxic for plant invaders as well as for the ultimate consumer of these plants (Thakur \& Sohal, 2013). Further, resistance 
development and species barrier are the major constraints limiting implications of breeding. So, it is direly needed to explore alternative strategies which are human friendly and provide broad-spectrum control of pathogens. Transgenic technology is only state-of-the-art technology that addresses all of the above-mentioned limitations paving way to develop environment friendly plant varieties having broad spectrum resistance against plant pathogens including fungi (Jach et al., 1995).

Engineering endogenous plant genes for fungal pathogen resistance: Overexpression of endogenous plant genes, inspite of alien genes is more attractive as far as commercialization of the engineered plants is concerned. Since various defense mechanisms have been explored in plants to withstand fungal pathogens. These mechansims can further be improved by engineering the most critical genes involved in these mechanisms. Sheath blight in rice may be controlled by the overexpression of two defense-related genes OsCHI11 and OsOxO4. OsCHI11 encodes for chitinase whereas $\mathrm{OsOxO}_{2}$ encodes for oxalate oxidase (Karmakar et al., 2016). Chitinase plays important role in degradation of chitin and hydrolyzes cell wall of pathogenic fungi (Muthukrishnan et al. 2001). Oxalate oxidase degrades oxalic acid by forming $\mathrm{CO} 2$ and $\mathrm{H} 2 \mathrm{O} 2$. At the site of infection, it destroys fungal virulence factor (Lane, 2000). Expression of these genes was controlled by green tissue specific promoters including rice cis-acting 544-bp DNA element and maize phosphoenolpyruvate carboxylase gene promoter (PEPC). In comparison with wild type, transgenic plants showed increased level of hydrogen peroxide, higher activity of ROS dependent enzymes and a remarkable reduction in infection and disease symptoms.

In potato, over-expression of endochitinase gene inhibited hyphal growth of Altenaria solani by $40 \%$ to $60 \%$ when assessed through quantitative in vitro assay. In comparison with wild type, there was a decrease in number of necrotic spots on the leaves of transgenic potatoes (Khan et al., 2016). PR-3(I) rice chitinase gene constutively expressed in rice plants increased the protection against Rhizoctonia solani (Lin et al., 1995). Overexpression of PR-5 in potato resulted in a delay in disease progression upon infection by Phytophthora infestans (Liu et al., 1994). Mixtures of purified PR-3(I) chitinase and $\beta-1,3-$ glucanase (PR-2 family) from tobacco showed synergistic antifungal activity in vitro (Sela-Buurlage et al., 1993). In tobacco the resistance against oomycete pathogens Peronospora tabacina and Phytophthora parasitica was increased by constitutive expression of the PR-1a gene (Alexander et al., 1993). Germins and germin like proteins (GLPs) play significant role in development and growth of plants. Expression of Oryza sativa root GLP2 promoter in potato. This promoter is activated in response to Fusarium solani and Alternaria solani. OsRGLP2 promoter activity was observed to be increased by 15 folds and 12 folds after infection with Fusarium solani and Alternaria solani Sorauer infection (Munir et al., 2015). Cultivated potato transformed with receptorlike protein ELR (elicitin response) taken from wild potato resulted in enhanced resistance to Phytophthora infestans. BAK1/SERK3 (immune receptors) associated ELR mediates broad-spectrum recognition of elicitin proteins from several Phytophthora species, including four diverse elicitins from P. infestans (Du et al., 2015). In orange fruits the monoterpene level was altered by down-regulation of a D-limonene synthase gene which leads to resistance against Penicillium digitatum infection. A resistant variety of ecotype Columbia against Fusarium oxysporum by overexpressing the thionin under constitutive promoters was developed. It was evaluated that phytopathogenic fungi induces the thionin Thi2.7 gene in Arabidopsis. The fungi with irregular hyphae including hyperbranching was grown on cotyledons of transgenic lines in comparison with wild type (Epple et al., 1997).

Cisgenic approaches to control fungal pathogens: Since, transgenic technology has no species barrier and any of the transgene may be expressed across the species. Ectopic expression of transgene has its own value and proved to be very effective in engineering crop plants for valuable traits. For fungal pathogen resistance, various genes have been recognized in yeast, fungi, bacteria and higher plants to have great antipathogenic activity. These genes may be exploited through transgenic technology and some research groups have attained excellent results (Table 1) (Grover \& Gowthaman, 2003). 
Table 1. Antifungal protein genes used for making fungus-resistant transgenic plants.

\begin{tabular}{|c|c|c|c|c|}
\hline $\begin{array}{l}\text { Fungal } \\
\text { pathogens }\end{array}$ & Name of the Gene & Source & Host plant & Reference \\
\hline $\begin{array}{l}\text { Rhizoctonia } \\
\text { solani } \\
\text { Pythium } \\
\text { aphanidermatum } \\
\end{array}$ & PR3 (Class Ichitinase) & $\begin{array}{l}\text { Bean (Phaseolus } \\
\text { vulgaris) }\end{array}$ & $\begin{array}{l}\text { Canola } \\
\text { (Brassica } \\
\text { napus) }\end{array}$ & $\begin{array}{l}\text { Broglie et al. } \\
\text { (1991) }\end{array}$ \\
\hline $\begin{array}{l}\text { Phytophthora } \\
\text { infestans }\end{array}$ & PR5 & Tobacco & $\begin{array}{l}\text { Potato } \\
\text { (Solanum } \\
\text { tuberosum) }\end{array}$ & Liu et al. (1994) \\
\hline $\begin{array}{l}\text { Rhizoctoniz } \\
\text { solani. Botrytus. } \\
\text { cinerea }\end{array}$ & PR3 (Classs II Chitinase), type I RIP & Barley & Tobacco & $\begin{array}{l}\text { Jach et al. } \\
\text { (1995) }\end{array}$ \\
\hline $\begin{array}{l}\text { Phytophthora } \\
\text { megasperma }\end{array}$ & PR2 (Class II Glucanase) & Alfalfa (M. sativa) & $\begin{array}{l}\text { Alfalfa } \\
\text { (Medicagi } \\
\text { sativa) }\end{array}$ & $\begin{array}{l}\text { Masoud et } \\
\text { al.(1996) }\end{array}$ \\
\hline $\begin{array}{l}\text { Phytophthora } \\
\text { infestans }\end{array}$ & PR5 & Potato (S. commersoni) & $\begin{array}{l}\text { Potato } \\
\text { (Solanum } \\
\text { tuberosum) }\end{array}$ & Zhu et al. (1996) \\
\hline $\begin{array}{l}\text { Cercospora } \\
\text { nicotianae } \\
\end{array}$ & $\begin{array}{l}\text { PR3 (Class I Chitibase), PR2 (Class II } \\
\text { Glucanase) }\end{array}$ & Alfalfa, Rice & Tobacco & Zhu et al. (1994) \\
\hline Botrytis cinerea & PR2 (class I glucanase) & Soybean (Glycine max) & $\begin{array}{l}\text { Kiwifruit } \\
\text { (Actinidia } \\
\text { chinensis) }\end{array}$ & $\begin{array}{l}\text { Nakamura Iet } \\
\text { al.I (1999) }\end{array}$ \\
\hline $\begin{array}{l}\text { Wheat } \\
\text { (Triticum } \\
\text { aestivum) }\end{array}$ & PR3 (Class II Chitinase) & Barley & $\begin{array}{l}\text { Wheat } \\
\text { (Triticum } \\
\text { aestivum) }\end{array}$ & $\begin{array}{l}\text { Bliffeld et al. } \\
\text { (1999) }\end{array}$ \\
\hline $\begin{array}{l}\text { Elisinoe } \\
\text { ampelina }\end{array}$ & PR3 (class I chitinase) & Rice (Oryza sativa) & $\begin{array}{l}\text { Grapevine } \\
\text { (Vitis vinifera) }\end{array}$ & $\begin{array}{l}\text { Yamamoto et al. } \\
(2000)\end{array}$ \\
\hline $\begin{array}{l}\text { Rhizoctonia } \\
\text { solani }\end{array}$ & Chitinase(RC7) & Rice & Rice & $\begin{array}{l}\text { Datta et al. } \\
(2001)\end{array}$ \\
\hline $\begin{array}{l}\text { Magnaporthe } \\
\text { grisea }\end{array}$ & Stress-inducible b-glucanase (Gns1) & Rice & Rice & $\begin{array}{l}\text { Nishizawa et al. } \\
(2003)\end{array}$ \\
\hline $\begin{array}{l}\text { Sclerotinia } \\
\text { homoeocarpa, } \\
\text { Rhizoctonia } \\
\text { solani }\end{array}$ & Chitinase(RCH10); Glucanase(ALG) & $\begin{array}{l}\mathrm{RCH} 10 \text { from rice; } \mathrm{ALG} \\
\text { from alfalfa }\end{array}$ & $\begin{array}{l}\text { Creeping bent } \\
\text { grass }\end{array}$ & $\begin{array}{l}\text { Wang et al. } \\
\text { (2003) }\end{array}$ \\
\hline $\begin{array}{l}\text { Rhizoctonia } \\
\text { solani }\end{array}$ & Chitinase(chi11) & Rice & Rice & $\begin{array}{l}\text { Kumar et al. } \\
(2003)\end{array}$ \\
\hline $\begin{array}{l}\text { Phytophthora } \\
\text { infestans, } \\
\text { Phytophthora } \\
\text { erythroseptica }\end{array}$ & Cationic peptide (msrA3) & Synthetic preparation & Potato & $\begin{array}{l}\text { Osusky et al. } \\
\text { (2004) }\end{array}$ \\
\hline $\begin{array}{l}\text { Rhizoctonia } \\
\text { solani }\end{array}$ & $\begin{array}{l}\text { Chitinase(ech42); Chitinase(nag70); } \\
\text { Glucanase(gluc78) }\end{array}$ & Trichoderma atroviride & Rice & Mei et al.(2004) \\
\hline $\begin{array}{l}\text { Magnaporthe } \\
\text { grisea }\end{array}$ & $\begin{array}{l}\text { Antifungal protein } \\
\text { (Afp) }\end{array}$ & $\begin{array}{l}\text { Aspergillus giganteus } \\
\text { (chemically } \\
\text { synthesized) }\end{array}$ & Rice & $\begin{array}{l}\text { Coca et al. } \\
(2004)\end{array}$ \\
\hline $\begin{array}{l}\text { Rhizoctonia } \\
\text { solani }\end{array}$ & $\begin{array}{l}\text { Chitinase(BjCHI1); } \\
\text { Glucanase(HbGLU) }\end{array}$ & $\begin{array}{l}\text { HbGLU from rubber } \\
\text { tree; BjCHI1 from } \\
\text { mustard }\end{array}$ & Potato & $\begin{array}{l}\text { Chye et al. } \\
(2005)\end{array}$ \\
\hline $\begin{array}{l}\text { Verticillium } \\
\text { dahliae }\end{array}$ & Chitinase(Chi) & Bean & Cotton & $\begin{array}{l}\text { Tohidfar et al. } \\
(2005)\end{array}$ \\
\hline
\end{tabular}




\begin{tabular}{|c|c|c|c|c|}
\hline Botrytis cinerea & $\begin{array}{l}\text { Chitinase(ch5B); Glucanase(gln2); } \\
\text { Antifungalprotein(ap24) }\end{array}$ & $\begin{array}{l}\text { ch5B from Beans } \\
\text { (Phaseolus vulgaris); } \\
\text { gln2 and ap24 from } \\
\text { tobacco }\end{array}$ & strawberry & $\begin{array}{l}\text { Vellicce et al. } \\
(2006)\end{array}$ \\
\hline $\begin{array}{l}\text { Ralstonia } \\
\text { solanacearum }\end{array}$ & $\begin{array}{l}\text { Glucanase(GLU);Antifungalprotein } \\
\text { (alfAFP);Glucanase(GLU-AFP) }\end{array}$ & $\begin{array}{l}\text { GLU from tobacco; } \\
\text { alfAFP from Alfalfa } \\
\text { Synthetically prepared }\end{array}$ & Tomato & $\begin{array}{l}\text { Chen et al. } \\
(2006)\end{array}$ \\
\hline $\begin{array}{l}\text { Magnaporthe } \\
\text { grisea }\end{array}$ & ER-CecA;Ap-CecA(CecropinA) & Synthetically prepared & Rice & $\begin{array}{l}\text { Coca et al. } \\
(2006)\end{array}$ \\
\hline $\begin{array}{l}\text { Fusarium } \\
\text { graminearum }\end{array}$ & $\begin{array}{l}\text { a-1-purothionin;tlp-1gene; b-1,3- } \\
\text { glucanase gene }\end{array}$ & $\begin{array}{l}\text { a-1-purothionin from } \\
\text { wheat; tlp-1 \&b-1,3- } \\
\text { glucanase from barley }\end{array}$ & Wheat & $\begin{array}{l}\text { Mackintosh et } \\
\text { al.(2005) }\end{array}$ \\
\hline $\begin{array}{l}\text { Magnaporthe } \\
\text { grisea, } \\
\text { Ustilaginoidea } \\
\text { virens, Tilletia } \\
\text { barclayana). }\end{array}$ & $\begin{array}{l}\text { Chitinases(RCH10\&RAC22);Glucanase } \\
\text { (b-Glu);Ribosomeinactivatingprotein } \\
\text { (B-RIP) }\end{array}$ & $\begin{array}{l}\text { RCH10 and RAC22 from } \\
\text { rice; b-Glu from alfalfa; } \\
\text { B-RIP from barley }\end{array}$ & Rice & Zhu et al.(2007) \\
\hline $\begin{array}{l}\text { Alternaria } \\
\text { brassicae }\end{array}$ & Glucanase & Tomato & Indian mustard & $\begin{array}{l}\text { Mondal et al. } \\
(2006)\end{array}$ \\
\hline Alternaria solant & Chitinase(ChiC) & Streptomyces griseus & Potato & $\begin{array}{l}\text { Raham et al. } \\
\text { (2008) }\end{array}$ \\
\hline $\begin{array}{l}\text { Rhizoctonia } \\
\text { solani }\end{array}$ & $\begin{array}{l}\text { Chitinase(chi11); } \\
\text { Glucanase(gluc) }\end{array}$ & $\begin{array}{l}\text { chi11 from rice; gluc } \\
\text { from Tobacco }\end{array}$ & Rice & $\begin{array}{l}\text { Sridevi et al. } \\
(2008)\end{array}$ \\
\hline $\begin{array}{l}\text { Botrytis cinerea } \\
\text { and Sclerotinia } \\
\text { sclerotiorum }\end{array}$ & $\begin{array}{l}\text { Chitinase383; } \\
\text { Glucanase638; } \\
\text { Cationic peroxidise(POC1) }\end{array}$ & $\begin{array}{l}\text { Chitinase and Glucanase } \\
\text { from Wheat; POC1 from } \\
\text { Rice }\end{array}$ & Carrot & $\begin{array}{l}\text { Wally et al. } \\
\text { (2008) }\end{array}$ \\
\hline $\begin{array}{l}\text { Trichoderma } \\
\text { harzanium }\end{array}$ & Chitinase (Chit30) & $\begin{array}{l}\text { Streptomyces } \\
\text { olivaceoviridis }\end{array}$ & Pea & $\begin{array}{l}\text { Hassan et al. } \\
(2009)\end{array}$ \\
\hline $\begin{array}{l}\text { Pyricularia } \\
\text { grisea }\end{array}$ & Chitinase (Chi11) & Rice & Finger millet & $\begin{array}{l}\text { Ignacimuthu \& } \\
\text { Ceasar (2012) }\end{array}$ \\
\hline \multicolumn{2}{|c|}{$\begin{array}{l}\text { Three barley proteins i.e. class-II } \beta \text {-1,3-glucanase, class- } \\
\text { II chitinase and a class-I ribosome inactivating protein } \\
\text { were expressed in tobacco under the control of } \\
\text { CaMV35S promoter. Chitinases and glucanases were } \\
\text { observed to be accumulated in intracellular spaces. } \\
\text { Fungal infection assayconfirmed expression as well as } \\
\text { antipathogenic activity against Rhizoctonia solani. Co- } \\
\text { expression of these genes appeared to be effective for } \\
\text { the control of pathogens as compared with single gene } \\
\text { (Jach et al., 1995). Co-production of chitinase and } \beta-1,3- \\
\text { glucanase resulted in a substantially higher protection } \\
\text { against Cercospora nicotianae than transgenic plant } \\
\text { expressing single gene (Zhu et al., 1994). Expression of } \\
\text { PR-3(I) chitinase or PR- 2(I) } \beta-1,3 \text {-glucanase genes in } \\
\text { tobacco plants showed no protection to infection against } \\
\text { Fusarium oxysporum. However, in tomato plants } \\
\text { simultaneous expression of both of these genes } \\
\text { decreased disease severity to } 40-60 \% \text { (Jongedijk et al., } \\
\text { 1995). Another study explained the combined } \\
\text { expression of a PR-3(II) chitinase gene (encoding an }\end{array}$} & \multicolumn{3}{|c|}{$\begin{array}{l}\text { extracellular isoform of chitinase) and a PR-2(II) } \beta \text {-1,3- } \\
\text { glucanase gene (encoding an extracellular isoform of } \beta \text { - } \\
\text { 1,3-glucanase) from bean in transgenic tobacco plants } \\
\text { increased the protection to Rhizoctonia solani infection } \\
\text { as compared with the tobacco plants expressing the } \\
\text { single transgene (Jach et al., 1995). Transgenic tobacco } \\
\text { plants expressing the barley class II chitinase and barley } \\
\text { RIP gene simultaneously showed improved protection to } \\
\text { R. solani attack as compared with the transformants with } \\
\text { single gene expression (Jach et al., 1995). } \\
\text { In tobacco and canola the constitutive expression of a } \\
\text { vacuolar isoform of chitinase (PR-3(I) family) from bean } \\
\text { reduces the susceptibility to Rhizoctonia solani (Broglie } \\
\text { et al., 1991). A chitinase gene was isolated from the soil } \\
\text { pathogen Seratia marcescens and was overexpressed in } \\
\text { tobacco. The resultant transgenic plants depicted } \\
\text { improved resistance to } R \text {. solani infection (Jach et al. } \\
\text { 1992). Constitutive expression of PR-3(I) chitinase genes } \\
\text { from rice in cucumber showed enhanced resistance } \\
\text { against Botrytis cinerea infection (Tabei et al., 1998). }\end{array}$} \\
\hline
\end{tabular}


Similalrly, expression of class I rice chitinase gene (RCC2) was studied in the somatic embryos of grapevine and resultant transformants showed enhanced resistance against Uncinula necator (causal agent of powdery mildew) (Yamamoto et al., 2000). Transgenic tobacco plants with recombinant barley RIP protein exhibited increased protection against Rhizoctonia solani infection (Logemann et al., 1992). Expression of pokeweed RIP gene (which encodes an antiviral protein that does not have ability to inhibit fungal growth when applied in vitro) in tobacco showed increased resistance against $R$. solani (Zoubenko et al., 1997).

Defensins are another important group of genes which play significant role in plant defense. In tobacco plant the expression of defensin gene from radish enhanced the tolerance against Alternaria longipes (Broekaert et al., 1997). Similarly, expression of alfaAFP from Medicago sativa to potato showed a great degree of resistance against Verticillium dahlia in green house as well as field conditions (Gao, et al., 2000). Transgenic potato (Solanum commersonii) plants expressing chimeric gene constructs comprising of sense or antisense RNAs under the control of cauliflower mosaic virus 35 promoter and a pA13 cDNA (for an osmotinlike protein) was developed. An increased level of resistance to Phytophthora infestans was observed in transgenic potato plants expressing pA13 (Zhu et al., 1996). The expression of Streptomyces griseus ChiC gene in combination with wasabi defensin (from Wasabia japonica) in potato plants was reported. Higher level of resistance against Fusarium oxysporum (causal agent of Fusarium wilt) and Alternaria solani was shownin transgenic lines (causal agent of early blight) (Khan et al., 2014).

Two stilbene synthase genes from grapevine were expressed in tobacco which don't have ability to produce resveratrol. Transgenic tobacco plants were able to produce resveratrol when infected with $B$. cinereal. Disease incidence was upto $50 \%$ in engineered plants (Honee, 1999). Stilbene synthase gene from grapevine was expressed in Carica papaya and resultant transformants depicted high level of tolerance against Phytophthora palmivora (Zhu et al., 2004). The production of the human lysozyme (an enzyme which is involved in the cleavage of $\beta-1,4-$ glycosidic linkage of chitin in the fungal cell wall) in tobacco plants was reported. The resultant transformants showed enhanced level of resistance to Erysiphe cichoracearum (Nakajima et al., 1997). In another study, transgenic potato plants were developed for the constitutive expression of $\mathrm{H} 2 \mathrm{O} 2$ generating glucose oxidase from Aspergillus niger. It resulted in increased resistance Phytophthora infestans, Verticillium dahliae and Alternaria solani (Wu et al., 1995).

Transgenic technology in combination with conventional breeding is even more valuable to develop pathogen resistant plants. pGreenII binary vector having chitinase gene from Streptomyces olivaceoviridis was used to engineer pea plants with bar gene as a selectable marker. Similarly, $\beta$-1,3-glucanase isolated from barley was transformed into another pea line. Both of the engineered pea lines were intercrossed to stack two antifungal proteins. At the same time, transgenic pea plants were also developed expressing both the chitinase and glucanase genes under constitutive 35-S promoter. In vitro assays of the cross bred pea plants and the plants with engineered glucanase and chitinase genes showed retardation of spore germination hence, were able to withstand fungal pathogen attack (Amian et al., 2011). Constitutive expression of Aglu1 (acidic glucanase) and $\mathrm{RCH} 10$ (rice basic chitinase) genes under CaMV35S (cauliflower mosaic virus) promoter resulted in decreased symptoms of fungal pathogen Phytophthora megasperma (Masoud et al., 1996)

The plant defensin NaD1, from Nicotiana alata, showed strong antifungal activity against a range of cotton pathogens including Fusarium oxysporum and Verticillium dahliae. NaD1 expressed in transgenic cotton plants appeared to be resistant against the infectious fungal pathogens. Crop productivity appeared to be increased by $200 \%$ as compared with non-transgenic cotton (Gaspar et al., 2014). Transgenic tomato plants expressing $\mathrm{rolB}$ gene evaluated its consequence on plant's nutritional content, morphology, yield and resistance against fungal pathogens. Transgenic tomato fruits have significant improvement in nutritional quality showed by biochemical analysis. Lycopene content was observed to be increased by $62 \%$ whereas total phenolics, ascorbic acid and free radical scavenging activity were observed to be increased by $225 \%, 58 \%$ and $26 \%$ respectively. Furthermore, defence response of leaves of transgenic plants was observed to be increased when infected with Fusarium oxysporum and Alternaria solani (Arshad et al., 2014). Over-expression of Osoxo4 (rice oxalate oxidase 4) gene in potato resulted in enhanced activity of oxalate oxidase enzyme thus with 
increased ability to degrade externally applied oxalic acid. After infection, the infectious fungal pathogens increased the levels of reactive oxygen species (H2O2) and defense related genes (anionic peroxidase and phenylalanine ammonia lyase) (Ghosh et al., 2016). Transgenic approach was used to develop sheath blight resistant varieties of rice. pZ100 gene expression cassette was developed by cloning AGLU1 (alfalfa $\beta-1,3-$ glucanase gene) and RCH1O (rice basic chitinase gene) under 35-S promoter with their enhancer sequences. Agrobacterium-mediated transformation method was used to transform pZ100 cassette into rice. Transgenic plants showed resistance to both blast and sheath blight (Mao et al., 2013). Likewise, genome editing has successfully been employed to develop crop plants having better ability to withstand fungal infection.

\section{CONCLUSIONS AND WAY FORWARD}

Plant diseases are an important constraint to crop productivity worldwide and account for more than $30 \%$ losses of the global harvest each year. Conventional research has contributed a lot and played critical role in the provision of disease free healthy foods to ever increasing population. Nevertheless, advancements in Molecular Biology has not only helped to explore plant pathogen interaction but also explored defense response of the plants. Developments in disease diagnosis through PCR and ELISA is a real milestone for the eradication of diseases including seed borne pathogens. Discovery of pathogenesis related proteins has helped breeders to stack multiple genes for broad spectrum resistance. In addition, developments in transgenic technology have proved much fruitful and a wide range of plants have been developed for enhanced pathogen resistance. Another advancement in science is genome editing which has addressed all of the concerns linked with transgenic technology and a large number of fungal pathogen resistant crop plants have been commercialized within last few years.

\section{REFERENCES}

Adams, D. J. 2004. Fungal cell wall chitinases and glucanases. Microbiology, 150: 2029-2035.

Adie, B. A. T., J. Perez-Perez, M. M. Perez-Perez, M. Godoy, J. J. Sanchez-Serrano, E. A. Schmelz and R. Solano. 2007. ABA Is an Essential Signal for Plant Resistance to Pathogens Affecting JA Biosynthesis and the Activation of Defenses in Arabidopsis. The Plant Cell Online, 19: 1665-1681.

Albersheim, P. and A. J. Anderson. 1971. Proteins from
Plant Cell Walls Inhibit Polygalacturonases Secreted by Plant Pathogens. Proceedings of the National Academy of Sciences, 68: 1815-1819.

Alexander, D., R. M. Goodman, M. Gut-Rella, C. Glascock, K. Weymann, L. Friedrich, D. Maddox, P. Ahl-Goy, T. Luntz and E. Ward. 1993. Increased tolerance to two oomycete pathogens in transgenic tobacco expressing pathogenesis-related protein $1 \mathrm{a}$. Proceedings of the National Academy of Sciences, 90: 7327-7331.

Amian, A. A., J. Papenbrock, H.-J. Jacobsen and F. Hassan. 2011. Enhancing transgenic pea (Pisum sativum L.) resistance against fungal diseases through stacking of two antifungal genes (chitinase and glucanase). GM crops, 2: 104-109.

Arshad, W., I.-u. Haq, M. T. Waheed, K. S. Mysore and B. Mirza. 2014. Agrobacterium-Mediated Transformation of Tomato with rolB Gene Results in Enhancement of Fruit Quality and Foliar Resistance against Fungal Pathogens. PLoS ONE, 9: e96979.

Baker, C. J. and E. W. Orlandi. 1995. Active Oxygen in Plant Pathogenesis. Annual Review of Phytopathology, 33: 299-321.

Bari, R. and J. D. G. Jones. 2008. Role of plant hormones in plant defence responses. Plant Molecular Biology, 69: 473-488.

Barna, B., J. Fodor, B. D. Harrach, M. Pogány and Z. Király. 2012. The Janus face of reactive oxygen species in resistance and susceptibility of plants to necrotrophic and biotrophic pathogens. Plant Physiology and Biochemistry, 59: 37-43.

Bartnicki-Garcia, S. 1968. Cell Wall Chemistry, Morphogenesis, and Taxonomy of Fungi. Annual Review of Microbiology, 22: 87-108.

Beckers, G. J. M. and S. H. Spoel. 2006. Fine-Tuning Plant Defence Signalling: Salicylate versus Jasmonate. Plant Biology, 8: 1-10.

Bliffeld, M., J. Mundy, I. Potrykus and J. Fütterer. 1999. Genetic engineering of wheat for increased resistance to powdery mildew disease. Theoretical and Applied Genetics, 98: 1079-1086.

Broekaert, W. F., B. P. A. Cammue, M. F. C. De Bolle, K. Thevissen, G. W. De Samblanx, R. W. Osborn and K. Nielson. 1997. Antimicrobial Peptides from Plants. Critical Reviews in Plant Sciences, 16: 297-323.

Broekaert, W. F., J. Van Parijs, A. K. Allen and W. J. Peumans. 1988. Comparison of some molecular, 
enzymatic and antifungal properties of chitinases from thorn-apple, tobacco and wheat. Physiological and Molecular Plant Pathology, 33: 319-331.

Brogue, K., I. Chet, M. Holliday, R. Cressman, P. Biddle, S. Knowlton, C. J. Mauvais and R. Broglie. 1991. Transgenic Plants with Enhanced Resistance to the Fungal Pathogen Rhizoctonia solani. Science, 254: 1194-1197.

Cervone, F., G. De Lorenzo, L. Degrà and G. Salvi. 1986. Interaction of Fungal Polygalacturonase with Plant Proteins in Relation to Specificity and Regulation of Plant Defense Response. Recognition in Microbe-Plant Symbiotic and Pathogenic Interactions. Springer Berlin Heidelberg, pp. 253258.

Chen, S. C., A. R. Liu and Z. R. Zou. 2006. Overexpression of glucanase gene and defensin gene in transgenic tomato enhances resistance to Ralstonia solanacearum. Russian Journal of Plant Physiology, 53: 671-677.

Chye, M.-L., K.-J. Zhao, Z.-M. He, S. Ramalingam and K.-L. Fung. 2004. An agglutinating chitinase with two chitin-binding domains confers fungal protection in transgenic potato. Planta, 220: 717-730.

Coca, M., C. Bortolotti, M. Rufat, G. Peñas, R. Eritja, D. Tharreau, A. M. del Pozo, J. Messeguer and B. San Segundo. 2004. Transgenic Rice Plants Expressing the Antifungal AFP Protein from Aspergillus Giganteus Show Enhanced Resistance to the Rice Blast Fungus Magnaporthe Grisea. Plant Molecular Biology, 54: 245-259.

Coca, M., G. Peñas, J. Gómez, S. Campo, C. Bortolotti, J. Messeguer and B. S. Segundo. 2005. Enhanced resistance to the rice blast fungus Magnaporthe grisea conferred by expression of a cecropin a gene in transgenic rice. Planta, 223: 392-406.

Couch, B. C., I. Fudal, M.-H. Lebrun, D. Tharreau, B. Valent, P. van Kim, J.-L. Nottéghem and L. M. Kohn. 2005. Origins of Host-Specific Populations of the Blast Pathogen Magnaporthe oryzae in Crop Domestication With Subsequent Expansion of Pandemic Clones on Rice and Weeds of Rice. Genetics, 170: 613-630.

Datta, K., J. Tu, N. Oliva, I. Ona, R. Velazhahan, T. W. Mew, S. Muthukrishnan and S. K. Datta. 2001. Enhanced resistance to sheath blight by constitutive expression of infection-related rice chitinase in transgenic elite indica rice cultivars. Plant Science, 160: 405-414.

De Vos, M., V. R. Van Oosten, R. M. P. Van Poecke, J. A. Van Pelt, M. J. Pozo, M. J. Mueller, A. J. Buchala, J.-P. Métraux, L. C. Van Loon, M. Dicke and C. M. J. Pieterse. 2005. Signal signature and transcriptome changes of arabidopsis during pathogen and insect attack. Molecular Plant-Microbe Interactions, 18: 923-937.

De Wit, P. J. G. M. 2007. How plants recognize pathogens and defend themselves. Cellular and Molecular Life Sciences, 64: 2726-2732.

Dean, R., J. A. L. Van Kan, Z. A. Pretorius, K. E. HammondKosack, A. Di Pietro, P. D. Spanu, J. J. Rudd, M. Dickman, R. Kahmann, J. Ellis and G. D. Foster. 2012. The Top 10 fungal pathogens in molecular plant pathology. Molecular Plant Pathology, 13: 414-430.

Du, J., E. Verzaux, A. Chaparro-Garcia, G. Bijsterbosch, L. C. P. Keizer, J. Zhou, T. W. H. Liebrand, C. Xie, F. Govers, S. Robatzek, E. A. G. van der Vossen, E. Jacobsen, R. G. F. Visser, S. Kamoun and V. G. A. A. Vleeshouwers. 2015. Elicitin recognition confers enhanced resistance to Phytophthora infestans in potato. Nature Plants, 1: 15034.

Epple, P. 1997. Overexpression of an Endogenous Thionin Enhances Resistance of Arabidopsis against Fusarium oxysporum. The Plant Cell Online, 9: 509-520.

Fisher, M. 2012. emerging fungal threats to animal, plant and ecosystem health: c8-2. Mycoses, 55: 79-80.

Fisher, M. C., D. A. Henk, C. J. Briggs, J. S. Brownstein, L. C. Madoff, S. L. McCraw and S. J. Gurr. 2012. Emerging fungal threats to animal, plant and ecosystem health. Nature, 484: 186-194.

Gao, A.-G., S. M. Hakimi, C. A. Mittanck, Y. Wu, B. M. Woerner, D. M. Stark, D. M. Shah, J. Liang and C. M. T. Rommens. 2000. Fungal pathogen protection in potato by expression of a plant defensin peptide. Nature Biotechnology, 18: 1307-1310.

Gaspar, Y. M., J. A. McKenna, B. S. McGinness, J. Hinch, S. Poon, A. A. Connelly, M. A. Anderson and R. L. Heath. 2014. Field resistance to Fusarium oxysporum and Verticillium dahliae in transgenic cotton expressing the plant defensin $\mathrm{NaD} 1$. Journal of Experimental Botany, 65: 1541-1550.

Ghosh, S., K. A. Molla, S. Karmakar, S. K. Datta and K. Datta. 2016. Enhanced resistance to late blight 
pathogen conferred by expression of rice oxalate oxidase 4 gene in transgenic potato. Plant Cell, Tissue and Organ Culture (PCTOC), 126: 429-437.

Grant, M. and C. Lamb. 2006. Systemic immunity. Current Opinion in Plant Biology, 9: 414-420.

Green, J. R., N. A. Pain, M. E. Cannell, C. P. Leckie, S. McCready, A. J. Mitchell, J. A. Callow, G. L. Jones, R. J. O'Connell and K. Mendgen. 1995. Analysis of differentiation and development of the specialized infection structures formed by biotrophic fungal plant pathogens using monoclonal antibodies. Canadian Journal of Botany, 73: 408-417.

Grover, A. and R. Gowthaman. 2003. Strategies for development of fungus-resistant transgenic plants. Current Science, 84: 330-340.

Gururani, M. A. and S. W. Park. 2012. Engineered resistance against filamentous pathogens in Solanum tuberosum. Journal of General Plant Pathology, 78: 377-388.

Haas, B. J., S. Kamoun, M. C. Zody, R. H. Jiang, R. E. Handsaker, L. M. Cano, M. Grabherr, C. D. Kodira, S. Raffaele and T. Torto-Alalibo. 2009. Genome sequence and analysis of the Irish potato famine pathogen Phytophthora infestans. Nature, 461: 393.

Hassan, F., J. Meens, H.-J. Jacobsen and H. Kiesecker. 2009. A family 19 chitinase (Chit30) from Streptomyces olivaceoviridis ATCC 11238 expressed in transgenic pea affects the development of T. harzianum in vitro. Journal of Biotechnology, 143: 302-308.

Honée, G. 1999. Engineered resistance against fungal plant pathogens. European Journal of Plant Pathology, 105: 319-326.

Ignacimuthu, S. and S. A. Ceasar. 2012. Development of transgenic finger millet (Eleusine coracana (L.) Gaertn.) resistant to leaf blast disease. Journal of Biosciences, 37: 135-147.

Islam, A. 2008. Fungus Resistant Transgenic Plants: Strategies, Progress and Lessons Learnt. Plant Tissue Culture and Biotechnology, 16.

Jach, G., B. Gornhardt, J. Mundy, J. Logemann, E. Pinsdorf, R. Leah, J. Schell and C. Maas. 1995. Enhanced quantitative resistance against fungal disease by combinatorial expression of different barley antifungal proteins in transgenic tobacco. The Plant Journal, 8: 97-109.

Jach, G., B. Görnhardt, J. Mundy, J. Logemann, E. Pinsdorf, R. Leah, J. Schell and C. Maas. 1995. Enhanced quantitative resistance against fungal disease by combinatorial expression of different barley antifungal proteins in transgenic tobacco. The Plant Journal, 8: 97-109.

Jones, J. D. G. and J. L. Dangl. 2006. The plant immune system. Nature, 444: 323-329.

Jongedijk, E., H. Tigelaar, J. S. C. van Roekel, S. A. BresVloemans, I. Dekker, P. J. M. van den Elzen, B. J. C. Cornelissen and L. S. Melchers. 1995. Synergistic activity of chitinases and $\beta$-1,3-glucanases enhances fungal resistance in transgenic tomato plants. Euphytica, 85: 173-180.

Jordan, I. K. 2009. Faculty of 1000 evaluation for Genome sequence and analysis of the Irish potato famine pathogen Phytophthora infestans. F1000 - Postpublication peer review of the biomedical literature. Faculty of 1000, Ltd.

Karmakar, S., K. A. Molla, P. K. Chanda, S. N. Sarkar, S. K. Datta and K. Datta. 2015. Green tissue-specific coexpression of chitinase and oxalate oxidase 4 genes in rice for enhanced resistance against sheath blight. Planta, 243: 115-130.

Keon, J., J. Antoniw, R. Carzaniga, S. Deller, J. L. Ward, J. M. Baker, M. H. Beale, K. Hammond-Kosack and J. J. Rudd. 2007. Transcriptional Adaptation of Mycosphaerella graminicolato Programmed Cell Death (PCD) of Its Susceptible Wheat Host. Molecular Plant-Microbe Interactions, 20: 178193.

Khan, A., I. A. Nasir, B. Tabassum, K. Aaliya, M. Tariq and A. Q. Rao. 2016. Expression studies of chitinase gene in transgenic potato against Alternaria solani. Plant Cell, Tissue and Organ Culture (PCTOC), 128: 563-576.

Khan, R. S., N. A. Darwish, B. Khattak, V. O. Ntui, K. Kong, K. Shimomae, I. Nakamura and M. Mii. 2014. Retransformation of marker-free potato for enhanced resistance against fungal pathogens by pyramiding chitinase and wasabi defensin genes. Molecular Biotechnology, 56: 814-823.

Kolmer, J. A. 1996. Genetics of resistance to wheat leaf rust. Annual Review of Phytopathology, 34: 435455.

Kumar, K. K., K. Poovannan, R. Nandakumar, K. Thamilarasi, C. Geetha, N. Jayashree, E. Kokiladevi, J. A. J. Raja, R. Samiyappan, D. Sudhakar and P. Balasubramanian. 2003. A high throughput functional expression assay system for a defence 
gene conferring transgenic resistance on rice against the sheath blight pathogen, Rhizoctonia solani. Plant Science, 165: 969-976.

Lane, B. G. 2000. Oxalate oxidases and differentiating surface structure in wheat: germins. Biochemical Journal, 349: 309-321.

Lee, W.-S., B. J. Devonshire, K. E. Hammond-Kosack, J. J. Rudd and K. Kanyuka. 2015. Deregulation of plant cell death through disruption of chloroplast functionality affects asexual sporulation of Zymoseptoria tritici on wheat. Molecular PlantMicrobe Interactions, 28: 590-604.

Lin, W., C. S. Anuratha, K. Datta, I. Potrykus, S. Muthukrishnan and S. K. Datta. 1995. Genetic Engineering of Rice for Resistance to Sheath Blight. Nature Biotechnology, 13: 686-691.

Liu, D., K. G. Raghothama, P. M. Hasegawa and R. A. Bressan. 1994. Osmotin overexpression in potato delays development of disease symptoms. Proceedings of the National Academy of Sciences, 91: 1888-1892.

Liu, M., Z.-x. Sun, J. Zhu, T. Xu, G. E. Harman and M. Lorito. 2004. Science Letters: Enhancing rice resistance to fungal pathogens by transformation with cell wall degrading enzyme genes fromTrichoderma atroviride. Journal of Zhejiang University Science, 5: 133-136.

Logemann, J., G. Jach, S. Logemann, R. Leah, G. Wolf, J. Mundy, A. Oppenheim, I. Chet and J. Schell. 1993. Expression of a Ribosome Inhibiting Protein (RIP) or a Bacterial Chitinase Leads to Fungal Resistance in Transgenic Plants. Developments in Plant Pathology. Springer Netherlands, pp. 446-448.

Logemann, J., G. Jach, H. Tommerup, J. Mundy and J. Schell. 1992. Expression of a Barley RibosomeInactivating Protein Leads to Increased Fungal Protection in Transgenic Tobacco Plants. Nature Biotechnology, 10: 305-308.

Mackintosh, C. A., D. F. Garvin, L. E. Radmer, S. J. Heinen and G. J. Muehlbauer. 2005. A model wheat cultivar for transformation to improve resistance to Fusarium Head Blight. Plant Cell Reports, 25: 313319.

Magan, N., D. Aldred, K. Mylona and R. J. W. Lambert. 2010. Limiting mycotoxins in stored wheat. Food Additives \& Contaminants: Part A, 27: 644-650.

Mao, B., X. Liu, D. Hu and D. Li. 2013. Co-expression of $\mathrm{RCH} 10$ and AGLU1 confers rice resistance to fungal sheath blight Rhizoctonia solani and blast Magnorpathe oryzae and reveals impact on seed germination. World Journal of Microbiology and Biotechnology, 30: 1229-1238.

Masoud, S. A., Q. Zhu, C. Lamb and R. A. Dixon. 1996. Constitutive expression of an inducible $\beta$-1,3glucanase in alfalfa reduces disease severity caused by the oomycete pathogen Phytophthora megasperma f. sp. medicaginis, but does not reduce disease severity of chitin-containing fungi. Transgenic Research, 5: 313-323.

Michielse, C. B. and M. Rep. 2009. Pathogen profile update: Fusarium oxysporum. Molecular Plant Pathology, 10: 311-324.

Mondal, K. K., R. C. Bhattacharya, K. R. Koundal and S. C. Chatterjee. 2006. Transgenic Indian mustard Brassica juncea expressing tomato glucanase leads to arrested growth of Alternaria brassicae. Plant Cell Reports, 26: 247-252.

Munir, F., S. Hayashi, J. Batley, S. M. S. Naqvi and T. Mahmood. 2015. Germin-like protein 2 gene promoter from rice is responsive to fungal pathogens in transgenic potato plants. Functional \& Integrative Genomics, 16: 19-27.

Muthukrishnan, S., G. H. Liang, H. N. Trick and B. S. Gill. 2001. Enhanced resistance to sheath blight by constitutive expression of infection-related rice chitinase in transgenic elite indica rice cultivars. Plant Cell, Tissue and Organ Culture, 64: 93-114.

Nakajima, H., T. Muranaka, F. Ishige, K. Akutsu and K. Oeda. 1997. Fungal and bacterial disease resistance in transgenic plants expressing human lysozyme. Plant Cell Reports, 16: 674-679.

Nakamura, Y., H. Sawada, S. Kobayashi, I. Nakajima and M. Yoshikawa. 1999. Expression of soybean b -1,3endoglucanase cDNA and effect on disease tolerance in kiwifruit plants. Plant Cell Reports, 18: 527-532.

Nelson-Smith, D. 1993. Brighton Crop Protection Conference 1993-Weeds: Introduction. Crop Protection, 12: 555-559.

Nishiuchi, T., D. Masuda, H. Nakashita, K. Ichimura, K. Shinozaki, S. Yoshida, M. Kimura, I. Yamaguchi and K. Yamaguchi. 2006. Fusarium phytotoxin trichothecenes have an elicitor-like activity in Arabidopsis thaliana, but the activity differed significantly among their molecular species. Molecular Plant-Microbe Interactions, 19: 512- 
520.

Nishizawa, Y., M. Saruta, K. Nakazono, Z. Nishio, M. Soma, T. Yoshida, E. Nakajima and T. Hibi. 2003. Characterization of transgenic rice plants overexpressing the stress-inducible $\beta$-glucanase gene Gns1. Plant Molecular Biology, 51: 143-152.

Nucci, M. and E. Anaissie. 2007. Fusarium Infections in Immunocompromised Patients. Clinical Microbiology Reviews, 20: 695-704.

Oerke, E. C. 2005. Crop losses to pests. The Journal of Agricultural Science, 144: 31.

Oerke, E. C. and H. W. Dehne. 2004. Safeguarding production-losses in major crops and the role of crop protection. Crop Protection, 23: 275-285.

Orton, E. S., S. Deller and J. K. M. Brown. 2011. Mycosphaerella graminicola: from genomics to disease control. Molecular Plant Pathology, 12: 413-424.

Osusky, M., L. Osuska, R. E. Hancock, W. W. Kay and S. Misra. 2004. Transgenic Potatoes Expressing a Novel Cationic Peptide are Resistant to Late Blight and Pink Rot. Transgenic Research, 13: 181-190.

Ou, S. H. 1980. Pathogen Variability and Host Resistance in Rice Blast Disease. Annual Review of Phytopathology, 18: 167-187.

Paciolla, C., N. Dipierro, G. Mulè, A. Logrieco and S. Dipierro. 2004. The mycotoxins beauvericin and T2 induce cell death and alteration to the ascorbate metabolism in tomato protoplasts. Physiological and Molecular Plant Pathology, 65: 49-56.

Pan, S.-Q., X.-S. Ye and J. Kuć. 1989. Direct detection of $\beta$ 1,3-glucanase isozymes on polyacrylamide electrophoresis and isoelectrofocusing gels. Analytical Biochemistry, 182: 136-140.

Park, S. W., E. Kaimoyo, D. Kumar, S. Mosher and D. F. Klessig. 2007. Methyl Salicylate Is a Critical Mobile Signal for Plant Systemic Acquired Resistance. Science, 318: 113-116.

Peng, X.-L., W.-T. Xu, Y. Wang, K.-L. Huang, Z.-h. Liang, W.-w. Zhao and Y.-B. Luo. 2009. Mycotoxin Ochratoxin A-induced cell death and changes in oxidative metabolism of Arabidopsis thaliana. Plant Cell Reports, 29: 153-161.

Perfect, S. E., H. B. Hughes, R. J. O'Connell and J. R. Green. 1999. Colletotrichum: A Model Genus for Studies on Pathology and Fungal-Plant Interactions. Fungal Genetics and Biology, 27: 186-198.

Pretorius, Z. A., R. P. Singh, W. W. Wagoire and T. S.
Payne. 2000. Detection of Virulence to Wheat Stem Rust Resistance Gene Sr31 in Puccinia graminis. f. sp. tritici in Uganda. Plant Disease, 84: 203-203.

Prusky, D. 1996. Pathogen quiescence in postharvest diseases. Annual Review of Phytopathology, 34: 413-434.

Reader, J. 2009. Potato: a history of the propitious esculent. Yale University Press.

Rutter, W. B., A. Salcedo, A. Akhunova, F. He, S. Wang, H. Liang, R. L. Bowden and E. Akhunov. 2017. Divergent and convergent modes of interaction between wheat and Puccinia graminis f. sp. tritici isolates revealed by the comparative gene coexpression network and genome analyses. BMC Genomics, 18.

Samanta, I. 2015. Classification of Fungi. Veterinary Mycology. Springer India, pp. 9-10.

Scholefield, P. and J. Morison. 2010. Assessment of economic cost of endemic pests and diseases on the Australian grape and wine industry. Grape and Wine Research and Development Corporation (GWRDC) project. Project number: GWR, 8.

Sela-Buurlage, M. B., A. S. Ponstein, S. A. Bres-Vloemans, L. S. Melchers, P. J. M. van den Elzen and B. J. C. Cornelissen. 1993. Only Specific Tobacco (Nicotiana tabacum) Chitinases and [beta]-1,3Glucanases Exhibit Antifungal Activity. Plant Physiology, 101: 857-863.

Selin, C., T. R. de Kievit, M. F. Belmonte and W. G. D. Fernando. 2016. Elucidating the Role of Effectors in Plant-Fungal Interactions: Progress and Challenges. Frontiers in Microbiology, 7.

Simmons, C. R. 1994. The Physiology and Molecular Biology of Plant 1,3--D-Glucanases and 1,3;1,4- -DGlucanases. Critical Reviews in Plant Sciences, 13: 325-325.

Singh, R. P., H. M. William, J. Huerta-Espino and G. Rosewarne. 2004. Wheat rust in Asia: meeting the challenges with old and new technologies. Proceedings of the 4th international crop science congress. The Regional Institute Ltd Gosford, Australia.

Sridevi, G., C. Parameswari, N. Sabapathi, V. Raghupathy and K. Veluthambi. 2008. Combined expression of chitinase and $\beta$-1,3-glucanase genes in indica rice (Oryza sativa L.) enhances resistance against Rhizoctonia solani. Plant Science, 175: 283-290.

Tabei, Y., S. Kitade, Y. Nishizawa, N. Kikuchi, T. Kayano, T. 
Hibi and K. Akutsu. 1998. Transgenic cucumber plants harboring a rice chitinase gene exhibit enhanced resistance to gray mold (Botrytis cinerea ). Plant Cell Reports, 17: 159-164.

Thakur, M. and B. S. Sohal. 2013. Role of Elicitors in Inducing Resistance in Plants against Pathogen Infection: A Review. ISRN Biochemistry, 2013: 1-10.

Tohidfar, M., M. Mohammadi and B. Ghareyazie. 2005. Agrobacterium -mediated transformation of cotton (Gossypium hirsutum) using a heterologous bean chitinase gene. Plant Cell, Tissue and Organ Culture, 83: 83-96.

Turner, R. S. 2005. After the famine: Plant pathology, Phytophthora infestans, and the late blight of potatoes, 1845-1960. Historical Studies in the Physical and Biological Sciences, 35: 341-370.

Van Baarlen, P., E. J. Woltering, M. Staats and J. A. L. Van Kan. 2007. Histochemical and genetic analysis of host and non-host interactions of Arabidopsis with three Botrytis species: an important role for cell death control. Molecular Plant Pathology, 8: 41-54.

Van Loon, L. 1997. Induced resistance in plants and the role of pathogenesis-related proteins: a review. European Journal of Plant Pathology (Netherlands).

Vellicce, G. R., J. C. D. Ricci, L. Hernández and A. P. Castagnaro. 2006. Enhanced Resistance to Botrytis cinerea Mediated by the Transgenic Expression of the Chitinase Gene ch5B in Strawberry. Transgenic Research, 15: 57-68.

Vivier, E. and B. Malissen. 2005. Innate and adaptive immunity: specificities and signaling hierarchies revisited. Nature Immunology, 6: 17-21.

Voegele, R. T. and K. W. Mendgen. 2011. Nutrient uptake in rust fungi: how sweet is parasitic life? Euphytica, 179: 41-55.

Walker-Simmons, M., L. Hadwiger and C. A. Ryan. 1983. Chitosans and pectic polysaccharides both induce the accumulation of the antifungal phytoalexin pisatin in pea pods and antinutrient proteinase inhibitors in tomato leaves. Biochemical and Biophysical Research Communications, 110: 194-199.

Wally, O., J. Jayaraj and Z. Punja. 2008. Comparative resistance to foliar fungal pathogens in transgenic carrot plants expressing genes encoding for chitinase, $\beta$-1,3-glucanase and peroxidise. European Journal of Plant Pathology, 123: 331-342.

Wang, X., N. Jiang, J. Liu, W. Liu and G.-L. Wang. 2014. The role of effectors and host immunity in plant-necrotrophic fungal interactions. Virulence, 5: 722-732.

Wang, Y., A. P. Kausch, J. M. Chandlee, H. Luo, B. A. Ruemmele, M. Browning, N. Jackson and M. R. Goldsmith. 2003. Cotransfer and expression of chitinase, glucanase, and bar genes in creeping bentgrass for conferring fungal disease resistance. Plant Science, 165: 497-506.

Wu, G. 1995. Disease Resistance Conferred by Expression of a Gene Encoding H2O2-Generating Glucose Oxidase in Transgenic Potato Plants. The Plant Cell Online, 7: 1357-1368.

Yamamoto, T., H. Iketani, H. Ieki, Y. Nishizawa, K. Notsuka, T. Hibi, T. Hayashi and N. Matsuta. 2000. Transgenic grapevine plants expressing a rice chitinase with enhanced resistance to fungal pathogens. Plant Cell Reports, 19: 639-646.

Yoshida, K., V. J. Schuenemann, L. M. Cano, M. Pais, B. Mishra, R. Sharma, C. Lanz, F. N. Martin, S. Kamoun, J. Krause, M. Thines, D. Weigel and H. A. Burbano. 2013. Correction: The rise and fall of the Phytophthora infestans lineage that triggered the Irish potato famine. eLife, 2.

Zhu, B., T. H. Chen and P. Li. 1996. Analysis of late-blight disease resistance and freezing tolerance in transgenic potato plants expressing sense and antisense genes for an osmotin-like protein. Planta, 198.

Zhu, H., X. Xu, G. Xiao, L. Yuan and B. Li. 2007. Enhancing disease resistances of Super Hybrid Rice with four antifungal genes. Science in China Series C: Life Sciences, 50: 31-39.

Zhu, Q., E. A. Maher, S. Masoud, R. A. Dixon and C. J. Lamb. 1994. Enhanced Protection Against Fungal Attack by Constitutive Co-expression of Chitinase and Glucanase Genes in Transgenic Tobacco. Nature Biotechnology, 12: 807-812.

Zhu, Y. J., R. Agbayani, M. C. Jackson, C. S. Tang and P. H. Moore. 2004. Expression of the grapevine stilbene synthase gene VST1 in papaya provides increased resistance against diseases caused by Phytophthora palmivora. Planta, 220: 241-250.

Zipfel, C. and G. Felix. 2005. Plants and animals: a different taste for microbes. Current Opinion in Plant Biology, 8: 353-360.

Zoubenko, O., F. Uckun, Y. Hur, I. Chet and N. Tumer. 1997. Plant resistance to fungal infection induced by nontoxic pokeweed antiviral protein mutants. Nature Biotechnology, 15: 992-996. 